\title{
264 years of change and persistence in an agrarian landscape: a case study from the Swiss lowlands
}

\author{
Matthias Bürgi · Daniel Salzmann · Urs Gimmi
}

Received: 12 May 2014/ Accepted: 16 March 2015/Published online: 29 March 2015

(C) Springer Science+Business Media Dordrecht 2015

\begin{abstract}
Context Century-long interaction between societies and their environment has shaped the cultural landscapes across Europe. Specific farming systems have persisted for long periods, and their abandonment has led to far-reaching and rapid changes in patterns of land use and land cover.

Objective Taking the example of the municipality of Limpach, located in the Swiss lowlands, we studied the dynamics of cultural landscape and related driving forces in a long-term perspective.

Methods Using various data types, we reconstruct 264 years of change and persistence and evaluated the processes involved. The sources permit not only the examination of land use and land cover change, but also linear elements (paths, waterways) and the study of changes in parcel structure.

Results For centuries, efforts to increase the intensity and productivity of agriculture, such as the socalled "melioration projects", which included extensive drainage of wetlands and the establishment of an efficient network of roads and paths, greatly influenced landscape changes. In the last few decades, driving forces not directly aiming at an intensification
\end{abstract}

M. Bürgi ( $₫)$ · D. Salzmann · U. Gimmi

Research Unit Landscape Dynamics, WSL Swiss Federal

Institute for Forest, Snow and Landscape Research,

Zürcherstrasse 111, 8903 Birmensdorf, Switzerland

e-mail: matthias.buergi@wsl.ch of agricultural production, but rather promoting ecologically valuable landscape elements, have left traces in the open landscape of Limpach.

Conclusions Changes are an inherent characteristic of cultural landscapes. However, the rates of changes are highly variable over time. While comparatively stable periods might be used as a reference/baseline and the region itself may be referred to as a traditional cultural landscape, such long periods should not be misinterpreted as being stable from a long term historical perspective.

Keywords Landscape history - Rates of change · Driving forces · Historical maps · Agricultural history · Switzerland

\section{Introduction}

Originally an activity of historical geographers, the study of landscape changes has become an important topic in landscape ecology and more recently an important approach used in landscape ecology (Rhemtulla and Mladenoff 2007) and land change science (Turner et al. 2007). Four major groups of studies can be identified: (a) descriptive approaches (Bender et al. 2005; Hamre et al. 2007), (b) studies focussing on specific trends, such as urbanization (Antrop 2004; Seto and Fragkias 2005), loss of wetlands (Gimmi et al. 2011) or agricultural abandonment (Gellrich and 
Zimmermann 2007), (c) studies examining the consequences of landscape changes on, for example, biodiversity (Olsson et al. 2000; Coppedge et al. 2001; Stouffer et al. 2006) or ecosystem services, such as regional climate (Schneider and Eugster 2007), and (d) analytical approaches attempting to understand the forces driving landscape changes (Bürgi et al. 2004; Long et al. 2007; Bieling et al. 2013). Landscapes are the sphere in which human acts and natural factors and processes are intertwined. Landscapes can therefore change due to changes in the natural system and/or in the social system (Bičík et al. 2001), and these changes in turn have effects on both systems alike. Thus, many of the frameworks suggested for the study of such social-ecological systems (Binder et al. 2013) can be applied to the study of landscape changes.

Current research focussing on the driving forces of landscape change is not often motivated by questions such as "Can landscape change be directed into a societally more desirable direction?" or "What factors are accelerating or slowing down the rate of landscape change?" (Schneeberger et al. 2007) and we believe that these aspects have thus far not yet received the attention they deserve. By focusing primarily on changes, the analysis of persistence and impeding and stabilizing factors in landscapes are largely neglected, despite the fact they may be highly relevant for planning and management (Bürgi et al. 2004).

Long-term studies of landscape change can only be conducted based on suitable historical sources, most often a series of historical maps which are necessarily consistent and comparable in quality and map content (Gimmi et al. 2011). The comparable map content determines, for example, whether the focus is on land cover changes (open land-forests-settlements) or whether land use changes (e.g., pasture vs. meadow) can be analysed. Limited source availability is relevant for a descriptive approach, and further accentuated in more analytical approaches since this limits the quantity of available information on potential forces driving the change observed.

Historical sources are not randomly available, but certain historical circumstances can lead to favorable source availability. Producing maps, which necessitates surveying the land, requires significant resources. Therefore historical maps were often initiated by government activities that required spatial information, such as tax collection that required cadastral maps, i.e. a detailed cartographic record of land ownership showing the location and structure of parcels (Cousins 2001; Hamre et al. 2007), or major infrastructural projects with an impact on the land.

In this paper we present a study on landscape changes in the agrarian municipality of Limpach, located in the Swiss lowlands, taking advantage of two such circumstances: cadastral maps available from the eighteenth century used for tax collection purposes and planning documents on an encompassing melioration project from the early twentieth century, that included river corrections, drainage and reparcelling, i.e. the re-arrangement of parcels into larger entities to enhance efficient farming. Both map series permit the analysis of landscape elements, often not included in studies of landscape change, such as different uses of agricultural land, land parcelling and linear elements (paths, waterways).

The municipality of Limpach is located in the Limpach valley, which as a whole has been the subject of a recent study on the driving forces in landscape change (Bürgi et al. 2010). In this study, landscape change is assessed with a focus on peat mining, which was prevalent in some parts of the Limpach valley. In the present paper, we zoom in on the municipality of Limpach, characterized by the favourable source situation outlined above. For this location, we specifically address the following research questions: How did the landscape change over the past 264 years? What aspects of the landscape are highly dynamic? What aspects show high persistence? What are the specific processes that transform agricultural landscapes?

With this study we therefore want to contribute to the analytical approaches attempting to understand the forces driving landscape changes (i.e. the fourth group of landscape change studies as listed at the beginning of the introduction), but also explicitly studying driving forces of landscape persistence.

\section{Study area}

The municipality of Limpach is located in the Limpach Valley, in the central Lowlands of Switzerland (Fig. 1). The municipality covers an area of 445 ha and is located at about 480 masl. The yearly average precipitation is $1000-1100 \mathrm{~mm}$ and the average temperature is $8.5^{\circ} \mathrm{C}$ (Luterbacher 1992). 
Fig. 1 The municipality of Limpach is located in the lowlands of Switzerland (data land cover: pixmaps ${ }^{\odot}$ 2013 swisstopo $(5704000$ 000), DEM: $\operatorname{dhm} 25^{\odot} 2013$ swisstopo (5704 000 000))

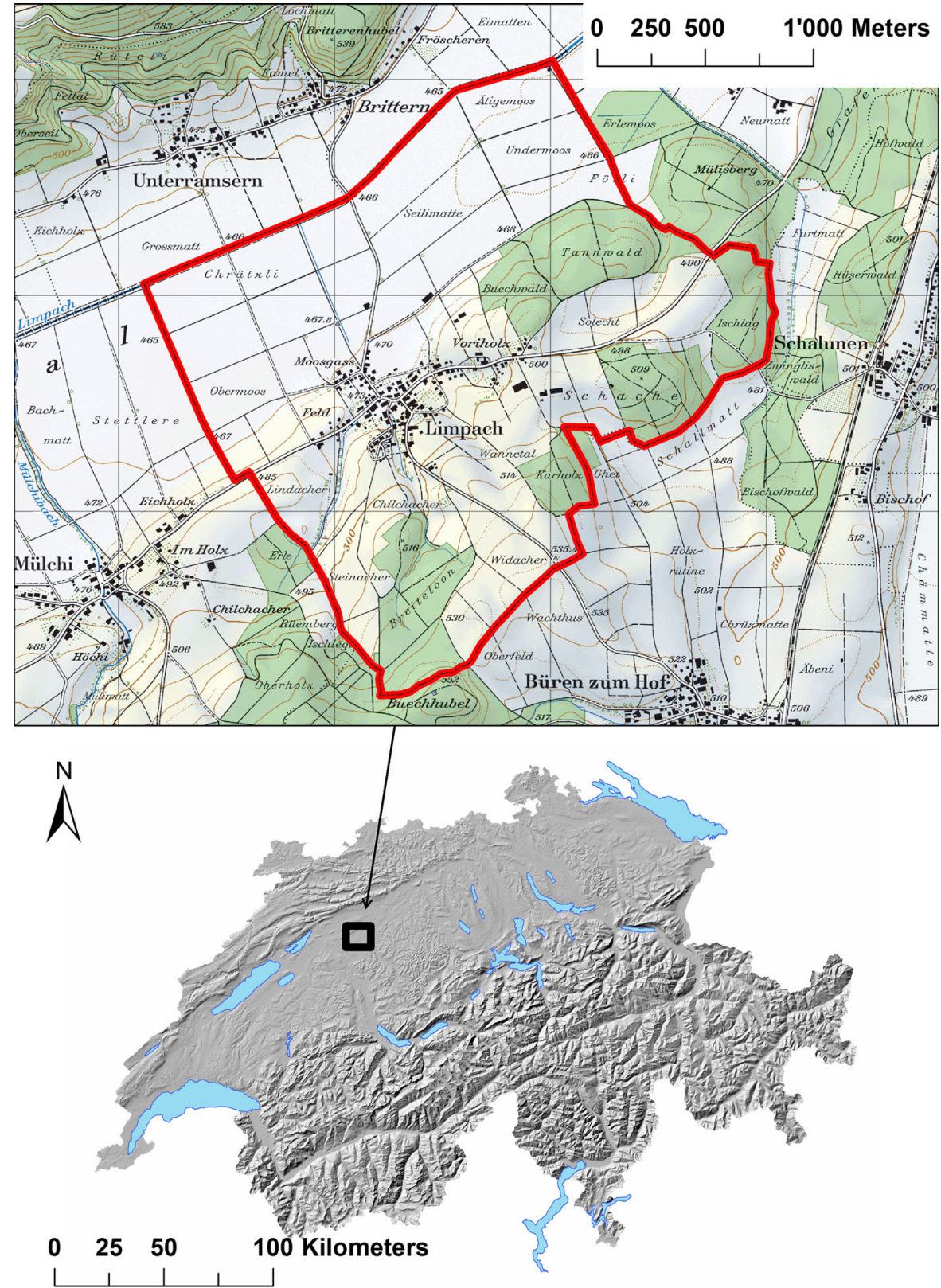

The study area consists of organic, partly peaty soils on the valley floor and mineral soils on the slopes and hills. In the 1940s, the average depth of the peat layer varied from 100 to $300 \mathrm{~cm}$ (Stähli 1941). Today, due to peat mining and drainage with subsequent mineralization, this depth is generally reduced.

Historically, due to its position in the lowlands, Limpach was part of the so-called "Grainland" ("Kornland"-Mathieu 1992), which encompassed most rural areas of the Swiss lowlands. Consequently, the main developments observed in the municipality of Limpach can be taken as an example of the trends occurring in large parts of the Swiss lowlands. Characteristic for the Grainland, grain production was a core land use and the arable land was cultivated according to the three-field system. In this land use system, which was common practice throughout large parts of Europe since about the thirteenth century 
(Pfister 1983; Renes 2014), about one-third of private land was sown in turn with winter grain, a second third with summer grain (oats, barley, beans), the last third remained fallow.

From the mid-eighteenth century onwards, an agricultural reform movement, the so-called agricultural revolution, spread from England to large parts of Europe, and resulted in Switzerland in the abandonment of this three-field system (Pfister 1983; Lowood 1987). The agrarian revolution also included the partitioning of common lands, the introduction of potatoes and legumes (e.g., clover, alfalfa), improvements in nutrient management through the introduction of summer stable feeding and dung collection, and-for Switzerland - the start of cheesemaking in the lowlands.

Today, Limpach is a largely rural municipality, and employment for some of the 341 inhabitants (http:// www.fin.be.ch/) is found in nearby larger towns and cities, such as Berne, the capital of Switzerland, which is only about $20 \mathrm{~km}$ away.

\section{Materials and methods}

Landscape change in Limpach was reconstructed based on historical maps, supplemented by historical documents and secondary literature, most of which were found at local, state, and federal libraries and archives. Despite the fact that not all maps show exactly the same land cover categories, we were able to build a remarkably thorough and homogenous documentation on landscape changes based on a series of historical maps with sufficient thematic overlap. The first map included in the study shows the situation before the agrarian revolution, as it dates from 1749. The original map consists of a series of single maps which were drawn by Jean David and Abraham Vissaula, who were famous for outstanding surveying in their day (Grosjean 1996). These 1749 maps, drawn at the approximate scale of 1:1450, show parcels, buildings, paths, waterways, fences and hedgerows. Information on ownership and land cover type (gardens, arable land, meadows, pastureland and forest areas) is listed in a separate volume ("Urbar"-details in Grosjean 1960). The aim of this survey was to have an overview of land ownership as a basis for tax collection. The second point in time considered is based on the first modern cadaster map of 1882, which was drawn on 15 sheets at a scale 1:1000. This maps shows approximately the same signatures as the 1749 map. Additional information on agricultural land use was taken from the contemporary cadastral register, however for some parcels, no information was available (white patches in Fig. 2). An encompassing drainage and melioration project conducted in the 1930s and 1940s was the reason for two more map series from 1939 (situation before the start of the project) and 1943 (situation after project completion). Both maps also include information on arable land, and artificial and natural meadows. The 1943 land use map does not cover the whole municipality of Limpach (white patch in the north-eastern corner in Fig. 2-1943). This gap only exists with reference to land cover information, whereas information on parcel boundaries, paths and waterways is available. The last step in time included in our study is the situation in around 2013, based on modern digital maps at a scale 1: 25,000 [Vektor25—swisstopo (DV033594)] combined with spatial and statistical information on the area under crop rotation obtained from the cantonal office for geoinformation (Amt für Geoinformation, Fruchtfolgeflächen des Kantons Bern). Since the crop rotation system leads to period changes between grassland and arable land, it does not make sense to attempt locating these land use types for a specific year. We introduced, for the last time step, a new land cover type called "crop rotation" and depicted only ecological compensation areas as permanent grasslands, as they are not part of the crop rotation system. However, based on the statistical data, we have information on the extent of grassland and arable land today, which makes it possible to calculate the total area and the proportion of the two land use types (Table 1).

All historical maps were scanned, the single map sheets georeferenced, mosaicked, and, together with the modern map, integrated into a geodatabase using ArcGIS 10.1 (ESRI). For the extraction of land-cover information, the modern map was taken as a reference layer on which the older maps were vectorized using a back-dating approach. This approach allows to redraw boundaries only for real changes, avoiding sliver polygons resulting from changes due to inaccuracies of older maps. From the GIS database, we calculated net changes in all analyzed signatures. For changes in settlements, forests, paths and waterways, we determined increases and decreases in area or length 


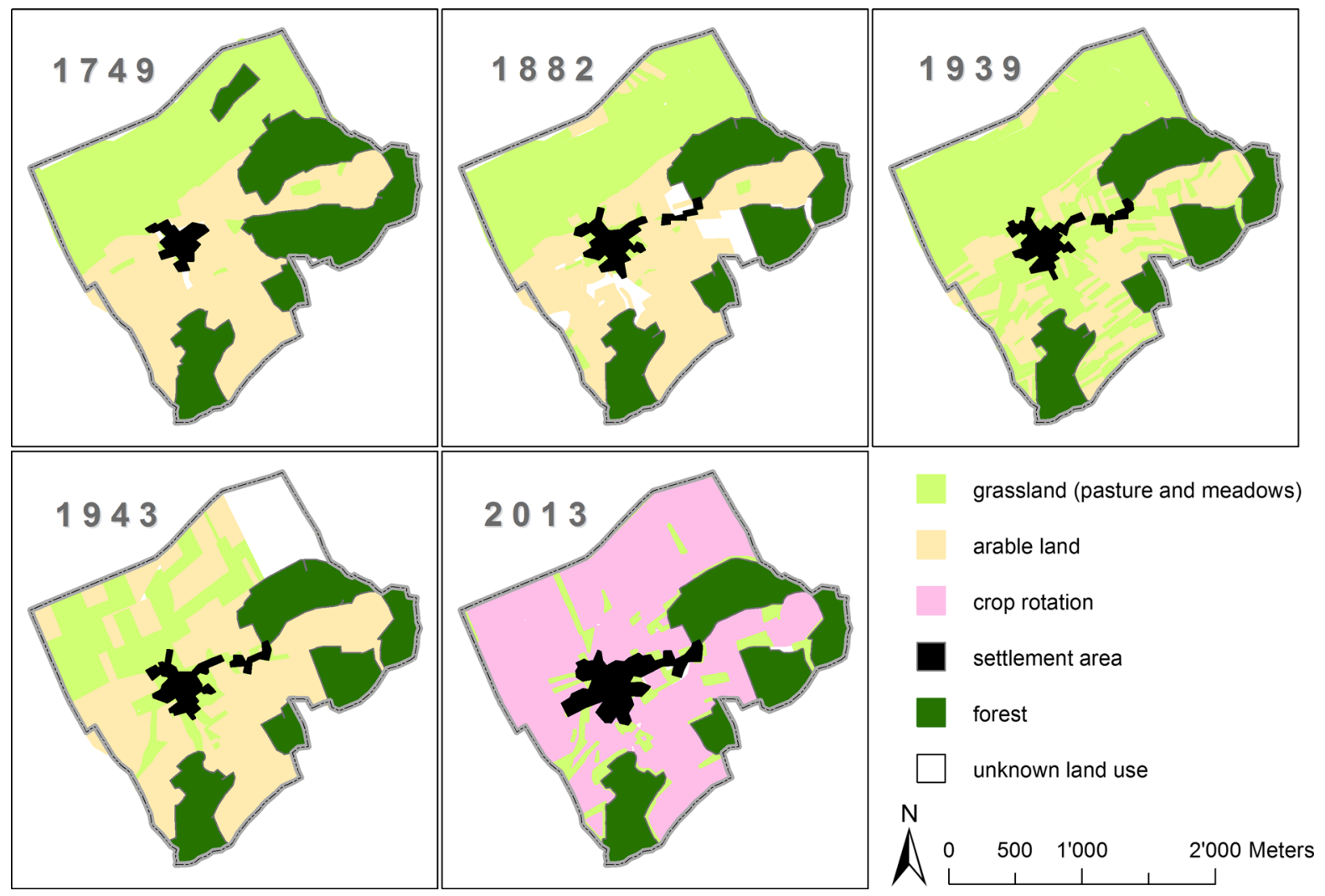

Fig. 2 Land cover in Limpach from 1749 to 2013. A large melioration and drainage project conducted between 1939 and 1943 enabled the conversion of formerly wet grassland in the northern part to arable land (sources discussed in text)

separately for all periods. For all other land cover categories, this comparison was only possible from 1749 to 1943 , as the modern crop rotation system does not permit such analysis for the last time step. We separately give the ratio of grassland to arable land, which reflects a core characteristic of the agricultural system. To account for large differences in length of periods between the maps, we also calculated annual relative changes.

Based on this map analysis, we determined the main trends of land cover change for 1749, 1882, 1939, 1943 and 2013. The changes and related driving forces were interpreted using information from the written documents and secondary literature. The oldest written document evaluated is a description of Limpach conducted by the local minister Müller (1804), containing information on land use at the beginning of the nineteenth century, a relatively short period before the beginning of the agricultural revolution in Limpach. Two reports (Stähli 1941,
1953) contain detailed information on the drainage and melioration project. Information on development that occurred in the twentieth century was taken from Straub (2008; see also Bürgi et al. 2010).

\section{Results}

Land cover and land use

In the first period from 1749 to 1882 , a slight expansion in settlements from 2 to $3 \%$ of the whole municipality, and a decline in forest area from 28 to $22 \%$ can be discerned (Fig. 2; Table 1). Agricultural land (i.e., the remaining 70-75\%) was about equally divided between grassland and arable land at both points in time (i.e. ratios of 0.95 and 0.98 , respectively). During the next 57 years, the major land cover classes remained stable, except for a significant expansion in grassland at the expense of arable land, 


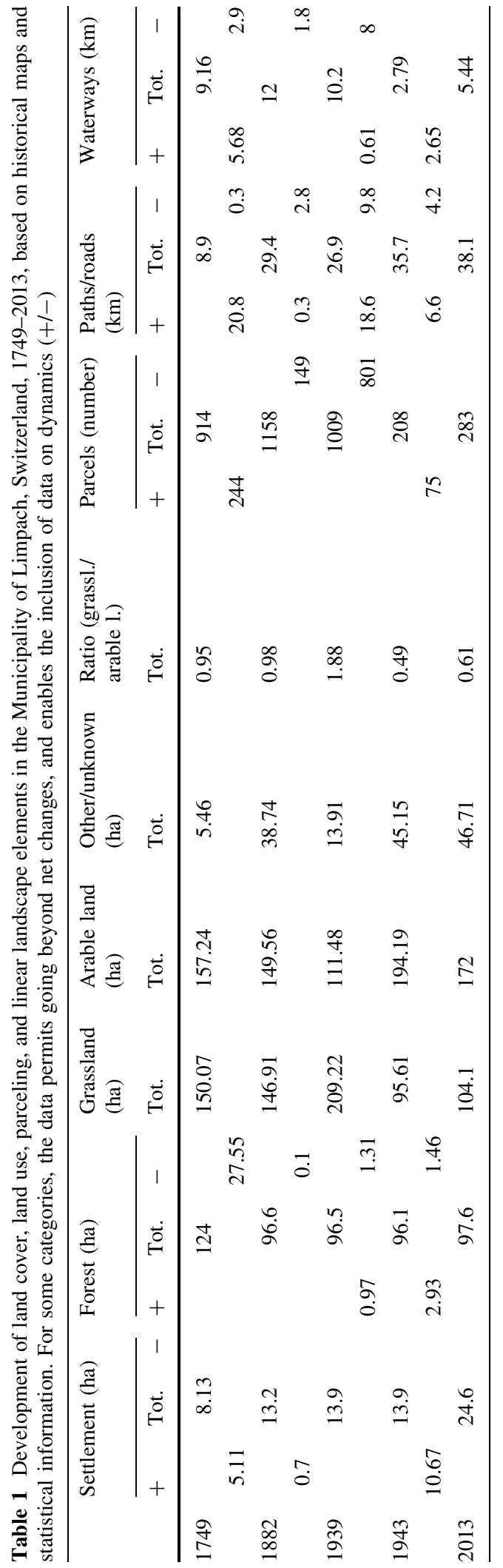

which by 1939 encompassed almost twice as much area as arable land (ratio of 1.88). Afterwards, within only 4 years, the proportion was reverted, i.e., the area of grassland was reduced by half and arable land doubled to a ratio of 0.49 . In the last period from 1943 to 2013, settlements doubled from 3 to $6 \%$, foremost at the expense of arable land. Also the number of houses almost doubled from 85 in 1943 to 156 in 2013, after a long stable period (1749: 79 houses, 1882: 87 houses, 1939: 98 houses). For the last time step, land cover data does not enable the allocation of grassland and arable land spatially, as today most of the agricultural land is managed in a crop rotation system ("Fruchtfolge"). However, the statistical data reveals that grassland increased slightly and arable land decreased, changing the ratio of grassland to arable land from 0.49 to 0.61 .

Parcels

In 1749, the area of the municipality used for agriculture was divided in 914 parcels (Fig. 3; Table 1) with a mean size of just 0.36 ha, and very few large patches of land (largest parcel: $47.6 \mathrm{ha}$ ). The largest patch (used as common land) was thereafter divided up into small parcels and consequently, until 1882, the total number of parcels grew by 244 to 1158 . By 1939, a few land consolidations reduced the number of parcels to 1009. Again, the next 4 years to 1943 brought major changes. A fundamental reallocation of land parcels led to a sharp decrease in their number by $83 \%$ to 208 . Since then, restructuring led to a rise in the number of parcels to 283 , with $91 \%$ of the additional parcels located in the areas where larger plots of agricultural land were subdivided and converted to into land for settlements.

\section{Road/path network}

The road and path network experienced considerable changes during the study period (Fig. 4; Table 1). In 1749 , large parts of the agricultural land were without paths, and only $8.9 \mathrm{~km}$ of paths were recorded on the map. This number increased to $29.4 \mathrm{~km}$ by 1882 , with $20.8 \mathrm{~km}$ of new paths built and only $0.3 \mathrm{~km}$ disappearing. During the following 57 years, some increase occurred, resulting in $26.9 \mathrm{~km}$ of roads and paths in 1939. The already impressive net change to $35.7 \mathrm{~km}$ 4 years later, hides an even greater dynamic as 


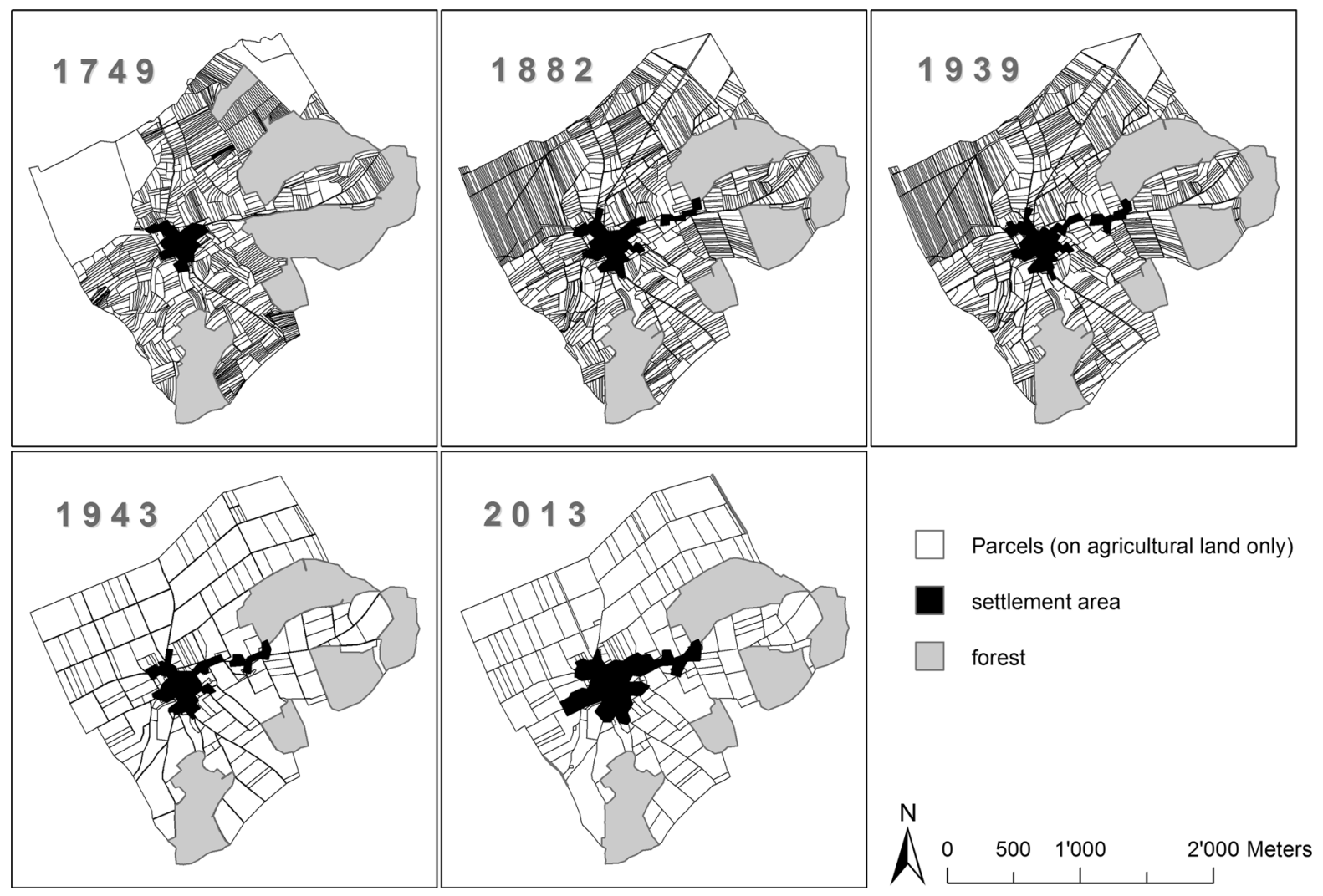

Fig. 3 Parcelling in Limpach from 1749 to 2013. The commons in the north-eastern corner were split up in 1771. A melioration project conducted between 1939 and 1943 resulted in a complete re-organization of the land to allow for more efficient farming (sources discussed in text)

in length, resulting from $5.7 \mathrm{~km}$ of new channels and $2.9 \mathrm{~km}$ loss of mostly meanders. With no major changes in the following 57 years, the total length dropped slightly to $10.2 \mathrm{~km}$ in 1939. Again, a major change occurred between 1939 and 1943. Most open channels disappeared $(-8.0 \mathrm{~km})$ in these 4 years and only very few new waterways were created, resulting in a $73 \%$ drop, which represents a large scale disappearance of water from the open landscape. In the last decades, some subterranean channels were reopened and the total length of waterways increased again from 2.8 to $5.4 \mathrm{~km}$.

Land use history

In our analysis of the land use history of Limpach, we focus on events which are likely to have an impact on aspects of land cover and landscape visible in the historical maps. Some information can be depicted on 


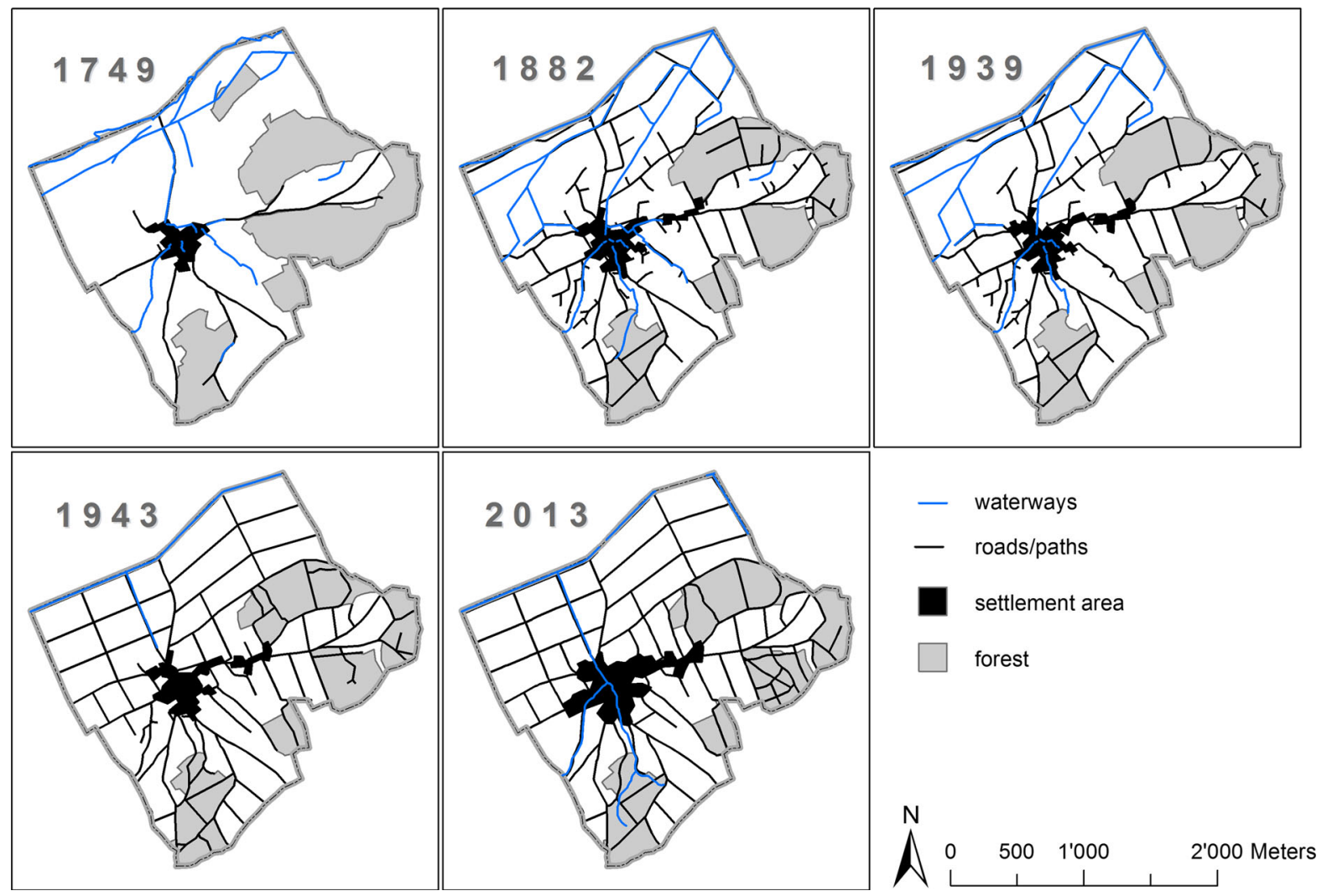

Fig. 4 Network of paths and roads and of waterways in Limpach from 1749 to 2013. In the three-field system (1749), the share of land taken by paths was minimized. A melioration project conducted between 1939 and 1943 resulted in a complete re-organization of the land to allow for more efficient farming (sources discussed in text)

Table 2 Timeline of land use in Limpach as compiled from historical sources

\begin{tabular}{|c|c|c|}
\hline Year & Event/process & Source \\
\hline ca. 1700 & Drainage channels built & Stähli (1941) \\
\hline 1771 & Partitioning of the common land & Müller (1804) \\
\hline $1780-1795$ & Limpach river straightened and deepened & Stähli (1941) \\
\hline ca. 1800 & $\begin{array}{l}\text { Summer stable feeding and clover introduced, half of fallow land converted } \\
\text { to permanent cultivation }\end{array}$ & Müller (1804) \\
\hline 1808 & Treaty: forest pasture will be abandoned but in turn a forest patch is cleared & Flückiger (1973) \\
\hline ca. $1830 \mathrm{~s}$ & $\begin{array}{l}\text { Abandonment of three-field system (1846: compulsory redemption of the } \\
\text { tenth in the Canton of Berne) }\end{array}$ & Pfister (1995) \\
\hline 1845 & Founding of cheese dairy & Stähli (1941) \\
\hline $1862-1866$ & Drainage corporation founded, additional channels built & Stähli (1941) \\
\hline $1938 / 1939$ & Several floods cause major damage on agricultural land & Stähli (1941) \\
\hline 1942 & Melioration project on 350 ha of land, including reparcelling, drainage on 255 ha, new paths & Stähli (1953) \\
\hline
\end{tabular}

a timeline of events and processes (Table 2). However, sources also shed light on continuous concerns and topics, which cannot be linked to single years. One such long-term endeavor in the municipality of Limpach is the improvement of the quality of the land for agriculture. Almost all land north of the 
settlement was very wet and prone to flooding. This land was not suitable as arable land (Fig. 2) until the 1942 melioration project, when some of it became dry enough to be ploughed and converted from grassland into arable land. While the continuous drainage efforts become manifest in the expansion of the drainage network and can be noted when comparing the maps from 1749 and 1939 (Fig. 4), this effect disappears on the surface thereafter, when new drainage technology permits the lowering of the water table without open channels.

The 1749 land cover map is typical for a municipality implementing the three-field system. All arable land, restricted to drier land at some distance from the river Limpach was laid out around the village. Only very few paths divided the land, as the management was organized in a way that the single farmer had access to his land, for example for the grain harvest, by his neighbors land, which already had to be harvested by this time. Large parts of the less productive lowland, but also the forest area were used as common pasture and therefore were not yet divided into parcels. In 1771, the partitioning of the common land led to an increase in the number of parcels. The abandonment of the three-field system in the first half of the nineteenth century further advanced the individual management of the farmland. Consequently, all parcels had to be accessible by a path, which triggered the massive expansion of the path network by 1882 .

From then on, it was largely up to the individual farmers to decide what to plant and grow on the land. The founding of the cheese dairy and the increase in grassland at the expense of arable land occurred throughout large parts of the Swiss lowlands in the second half of the nineteenth century ("Vergrünlandung", Pfister 1995). Climatic and soil conditions were more favorable for dairy farms and meat production, as at the same time the expansion of the railroad network made it possible to import grain from abroad, making domestic grain production less profitable.

This trend towards more grassland was reverted fundamentally in the above mentioned 1942 melioration project. The whole Limpach valley was affected by this fundamental remodeling of the agricultural land (Bürgi et al. 2010) and the effects within the municipality of Limpach on land cover, parceling, and the path and waterway networks were profound (Fig. 2; Table 1). The timing of the project can partly be explained by flooding in 1938 and 1939 (see Fig. 3 in Bürgi et al. 2010), but even more so by World War II. Switzerland, which was not directly affected by the war, underwent efforts to increase domestic food production by giving out federal subsidies for melioration projects, aiming at more intensive farming. Reducing the number of parcels, draining land for the purpose of growing crops on land which otherwise would only have served as grassland, and establishing a straight and clear network of paths were core elements of all these projects (Eidgenössisches Meliorationsamt 1947). In Limpach, the river was lowered and $124 \mathrm{~km}$ of clay drainage tubes, and $8 \mathrm{~km}$ of cement tubes helped to get the water off the land efficiently. $17.8 \mathrm{~km}$ of paths were newly built, and $2.8 \mathrm{~km}$ of paths were improved (Stähli 1953). The consequences of the melioration project for landscape appearance were profound: uniform large plots of farmland structured only by a rectangular network of paths dominates large parts of Limpach up to the present day (Fig. 5). In 1929, Limpach included 47 farms, for which there were 38 full-time farmers (numbers given in Stähli 1941). In 2012, only 11 farms are operational (http://www.bfs.admin.ch).

\section{Discussion}

Landscape changes and persistence

Over the past 264 years, almost all aspects of landscape and land cover considered showed their

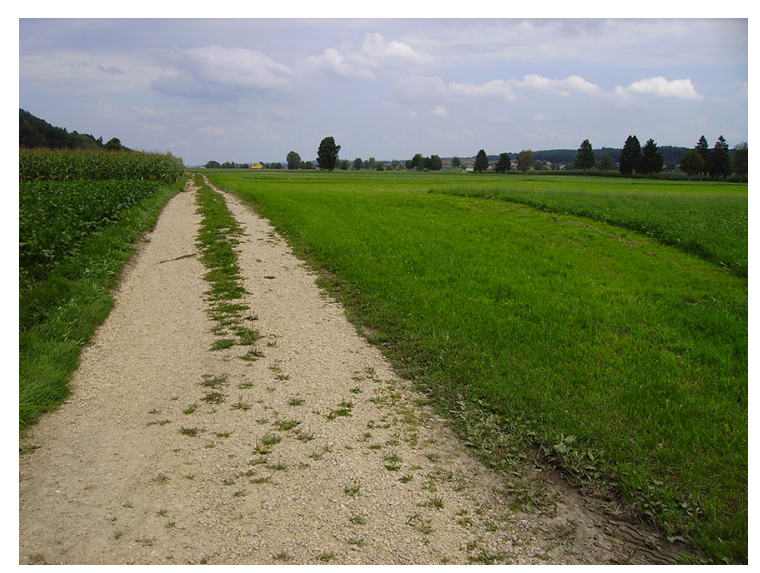

Fig. 5 A network of straight, rectangular paths, dating back to the melioration project in the 1940 s, today structures the agricultural landscape of Limpach (photo MB) 
largest annual change in the period 1939-1943 (Table 3). Exceptions are settlements, which increased foremost in the last period, and forest area, which showed remarkable stability (Fig. 2), except for the first period, in which a few forest patches had been cleared.

We may thereby conclude that landscape change was neither uniform nor continuous, but that major changes occurred in the course of one specific project, i.e., the melioration project devised to increase agricultural production triggered by attempts to increase self-sufficiency during World War II. We were fortunate to find sources depicting the situation directly before and after this project was carried out, as otherwise the annual rate of change would have been averaged out over a longer period, hiding how drastic the changes were.

\section{Driving forces}

All changes noted throughout the first 200 years were caused by attempts to increase agricultural productivity, through more intensive cultivation. The demand to drain the northern part of the municipality along the

Table 3 Compilation of main changes and persistencies in land use and land cover in the municipality of Limpach in the four periods defined by the historical maps used. Major river Limpach has been a constant theme throughout the last centuries. Technological innovation, such as the invention of clay drainage tubes in the late nineteenth century, which allowed for more efficient drainage (Pfister 1995), and finally the crises of World War II, brought these plans forward, causing massive changes in the land. How widespread this type of melioration process was, is well expressed in the fact that in the short period between 1940 and 1946, in Switzerland about 22,000 ha of land were drained (Eidgenössisches Meliorationsamt 1947). Consequently, the former clear separation of arable land and grassland in the landscape (Fig. 2) disappeared, as excessive soil moisture was no longer hindering the ploughing of parcels in lower areas.

The trend towards intensification of agriculture was for the first time reverted in the last period of the study presented, in which an increasing share of the growing population was no longer directly living from the land, but rather from other economic sectors. We see for example the steady decline in waterways to be reverted, which is a sign of a process called "greening", in which ecologically valuable landscape elements are increasingly re-introduced in

changes occured in the short period 1939-1943, in which a melioration project remodeled large parts of the landscape

\begin{tabular}{|c|c|c|c|c|}
\hline & 1749-1882 & $1882-1939$ & 1939-1943 & 1943-2013 \\
\hline Length (years) & 133 & 57 & 4 & 70 \\
\hline $\begin{array}{l}\text { Main change in } \\
\text { land use }\end{array}$ & $\begin{array}{c}\text { Agricultural } \\
\text { revolution }\end{array}$ & & Melioration project & \\
\hline $\begin{array}{l}\text { Change (i.e. } \\
\text { relative changes } \\
>1 \% \text { p.a.) }\end{array}$ & Paths $+1.8 \%$ & $\begin{array}{l}\text { Ratio grass-/arable land } \\
\quad+1.6 \%\end{array}$ & $\begin{array}{l}\text { Ratio grass-/arable land - } \\
\quad 18.4 \% \\
\text { Parcels }-19.9 \% \\
\text { Paths }+17.3 /-9.1 \% \\
\text { Waterways }+1.5 /- \\
19.7 \%\end{array}$ & $\begin{array}{l}\text { Settlements }+1.1 \% \\
\text { Waterways }+1.4 \%\end{array}$ \\
\hline $\begin{array}{l}\text { Main driving force } \\
\text { of change }\end{array}$ & $\begin{array}{l}\text { Agrarian revolution } \\
\text { (enlightenment) }\end{array}$ & $\begin{array}{l}\text { Demand for dairy products } \\
\text { and meat, mechanization } \\
\text { of agriculture }\end{array}$ & $\begin{array}{l}\text { Demand for domestic } \\
\text { production, } \\
\text { motorization of } \\
\text { agriculture }\end{array}$ & $\begin{array}{l}\text { Demand for housing, } \\
\text { demand for ecological } \\
\text { compensation }\end{array}$ \\
\hline $\begin{array}{l}\text { Persistency (i.e. } \\
\text { relative changes } \\
<0.1 \% \text { p.a.) }\end{array}$ & $\begin{array}{l}\text { Grassland } \\
\text { Copland }\end{array}$ & $\begin{array}{l}\text { Settlements } \\
\text { Forest } \\
\text { Paths }\end{array}$ & $\begin{array}{l}\text { Settlements } \\
\text { Forest }\end{array}$ & $\begin{array}{l}\text { Forest } \\
\text { Grassland }\end{array}$ \\
\hline $\begin{array}{l}\text { Main driving force } \\
\text { of persistency }\end{array}$ & $\begin{array}{l}\text { Agricultural system } \\
\text { (before the agrarian } \\
\text { revolution) }\end{array}$ & Forest law & Forest law & $\begin{array}{l}\text { Forest law, zoning } \\
\text { regulations }\end{array}$ \\
\hline
\end{tabular}


an otherwise highly intensively used agricultural landscape (Hersperger and Bürgi 2009). This means that for the first time in history, in all probability, driving forces not directly aiming at an intensification of agricultural production start to leave traces in the open landscape of Limpach.

The observed persistence of forests is the result of the strong legal protection status that forest areas have in Switzerland, especially since the establishment of the Swiss Federal Forestry Law which became effective for lowland forests in 1902. Also the long-lasting persistence of settlements before the last periods can be seen as a result of the legal constraints on land use going back to the three-field system in which the spatial organization of a village with a closed settlement surrounded by the agricultural land was prescribed.

Including linear elements in the analysis

It is advantageous not to limit the study of landscape change to land cover alone, but also including linear elements, such as the path and waterway networks and parcelling. For example, land cover showed only minor changes in agricultural land in the first study period and the ratio of arable land to grassland remained stable. Extensive changes in the path network, however, reflect the farmers' need to access their individual plots, and parcelling maps reflect the partitioning of common land. Both of these processes are consequences of the agricultural revolution taking place in this period (Table 3). Path networks together with parcelling reflect the way the land is organized, which is again visible in the major changes between 1939 and 1943, where modern ideas of efficiency start to leave traces in the landscape (Fig. 5).

\section{Methodological considerations}

Despite using multiple sources, our analysis of change and persistence is primarily based on historical maps, which have specific limitations that have to be taken into account (see Gimmi et al. 2011). We know for example from other studies that the characteristics of forest, but of course also of the other land cover types, changed over time, i.e. the forests delineated in the map of 1749 were very different to the forests of today in regards to growing stock, species composition, and use and management (see for example Bürgi 1999).
Moreover, forests and agricultural land was not always clearly separated, and especially the boundaries between the common pasture and forests were often a gradient of stocking density extending over a longer distance, as forests were legally a part of the commons and general pasture land. We consider this aspect to be of minor importance in the case presented, as-with the exception of small stretch in the north-eastern corner of Limpach-all forests delineated on the map of 1749 were surrounded by individual parcels, and did not share a boundary with the common land (Fig. 3).

Maps only provide snapshots for specific points in time. Additional information has to be considered to assess how dynamic the system was between these points in time. For example, with regards to the situation in 2013, we know that, in the modern crop rotation system, the distribution of grassland and arable land can change from year to year. This fact can therefore be properly taken into consideration in our analysis.

\section{Conclusion}

For the proper study of landscape dynamics, considering not only changes, but also persistence is meaningful and provides valuable insights into stabilizing factors as well as factors fostering changes. In the case study presented, persistence in land cover classes such as forests and settlements is caused by legal constraints. It might be interesting to test in further studies, which additional factors, such as e.g. natural constraints, can further act as stabilizing factors, depending on the specific context. If society considers the rate of landscape change to be too high, such studies might provide valuable insights what additional factors might help to slow down this process apart from the legal restrictions which show to be a powerful measure in the case study presented.

In the study of Limpach, we went beyond analysing land cover changes, and included information on the development of linear elements, such as paths, waterways and parcel boundaries. We propose that these two approaches are valuable strains of research in order to analyze driving forces in landscape change and provide basic information on stabilizing and destabilizing factors for cultural landscapes. 
In our study, we determined two main processes of land use change: first, changes due to the agricultural revolution of the eighteenth and nineteenth centuries, and second, the broad melioration projects that intended to enable more intensive agriculture based on large, more easily accessible parcels, and improved growing conditions through improved drainage. We suggest that similar processes were at work in many parts of Europe. Areas in which the second process (i.e., twentieth century melioration projects) did not take place, are often labelled "traditional cultural landscapes" (Cousins 2001; Bender et al. 2005; Hamre et al. 2007). However, in most cases, these landscapes have also been reshaped and reorganized due to the first process, i.e., the agricultural revolution and attendant and related changes caused by changes in farming intensity.

Changes are an inherent characteristics of cultural landscapes. However, the rates of changes are highly variable over time. While comparatively stable periods, such as the one we determined for our study region from the mid-nineteenth century up to World War II, might be used as a reference/baseline and the region itself may be referred to as a traditional cultural landscape, such periods should not be misinterpreted as being stable from a historical perspective.

Acknowledgments Data used in this study was collected in a project funded by the Swiss State Secretary for Education and Research (http://www.sbf.admin.ch) in the framework of COST A27 "understanding pre-industrial structures in rural and mining landscapes (LANDMARKS)".

\section{References}

Antrop M (2004) Landscape change and the urbanization process in Europe. Landsc Urban Plan 67:9-26

Bender O, Boehmer HJ, Jens D, Schumacher KP (2005) Using GIS to analyse long-term cultural landscape change in southern Germany. Landsc Urban Plan 70:111-125

Bičík I, Jeleček L, Štěpánek V (2001) Land-use changes and their social driving forces in Czechia in the 19th and 20th centuries. Land Use Policy 18:65-73

Bieling C, Plieninger T, Schaich H (2013) Patterns and causes of land change: empirical results and conceptual considerations derived from a case study in the Swabian Alb, Germany. Land Use Policy 35:192-203

Binder CR, Hinkel J, Bots PWG, Pahl-Wostl C (2013) Comparison of frameworks for analyzing social-ecological systems. Ecol Soc 18:26

Bürgi M (1999) A case study of forest change in the Swiss lowlands. Landscape Ecol 14:567-575
Bürgi M, Hersperger A, Schneeberger N (2004) Driving forces of landscape change-current and new directions. Landscape Ecol 19:857-868

Bürgi M, Straub A, Gimmi U, Salzmann D (2010) The recent landscape history of Limpach valley, Switzerland: considering three empirical hypotheses on driving forces of landscape change. Landscape Ecol 25:287-297

Coppedge BR, Engle DM, Masters RE, Gregory MS (2001) Avian response to landscape change in fragmented southern Great Plains grasslands. Ecol Appl 11:47-59

Cousins SAO (2001) Analysis of land-cover transitions based on 17th and 18th century cadastral maps and aerial photographs. Landscape Ecol 16:41-54

Flückiger M (1973) Von den Waldern der Landvogtei Fraubrunnen. Chronik des Amtes Fraubrunnen

Gellrich M, Zimmermann NE (2007) Investigating the regionalscale pattern of agricultural land abandonment in the Swiss mountains: a spatial statistical modelling approach. Landsc Urban Plan 79:65-76

Gimmi U, Lachat T, Bürgi M (2011) Wetland cover change in the Swiss lowlands since 1950. Landscape Ecol 26:1071-1083

Grosjean G (1960) Landvermessung und Kartographie des Kantons Bern, 2. Teil: Kantonaler Karten- und Plankatalog Bern. Staatlicher Lehrmittelverlag, Bern

Grosjean G (1996) Geschichte der Kartographie. Geographica Bernensia U8

Hamre LN, Domaas ST, Austad I, Rydgren K (2007) Landcover and structural changes in a western Norwegian cultural landscape since 1865 , based on an old cadastral map and a field survey. Landscape Ecol 22:1563-1574

Hersperger AM, Bürgi M (2009) Going beyond landscape change description: quantifying the importance of driving forces of landscape change in a Central Europe case study. Land Use Policy 26:640-648

Long HL, Tang GP, Li XB, Heilig GK (2007) Socio-economic driving forces of land-use change in Kunshan, the Yangtze River Delta economic area of China. J Environ Manag 83:351-364

Lowood HE (1987) Patriotism, profit, and the promotion of science in the German Enlightenment: the economic and scientific societies, 1760-1815. PhD Thesis, University of California, Berkeley

Luterbacher J (1992) Das Limpachtal—geografische Übersicht und Stickstoffbelastung eines ländlichen Gebietes im Schweizer Mittelland. Zweitarbeit im Hauptfach Geographie am Geografischen Institut der Universität Bern, pp 1-59

Mathieu J (1992) Eine Agrargeschichte der inneren Alpen. Chronos, Zürich

Meliorationsamt Eidgenössisches (1947) Bericht über das Meliorationswesen der Schweiz 1940-1946. Das ausserordentliche Meliorationsprogramm, Bern

Müller (1804) Beschreibung der Kirchgemeinde Limpach. Reprint in Stähli 1941

Olsson EGA, Austrheim G, Grenne SN (2000) Landscape change patterns in mountains, land use and environmental diversity, Mid-Norway 1960-1993. Landscape Ecol 15:155-170

Pfister C (1983) Changes in stability and carrying capacity of lowland and highland agro-systems in Switzerland in the historical past. Mt Res Dev 3:291-297

Pfister C (1995) Geschichte des Kantons Bern seit 1798. Band IV. Im Strom der Modernisierung. Bevölkerung, Wirtschaft und Umwelt 1700-1914. Bern 1995 
Renes J (2014) Die offenen von Ackerbau geprägten Landschaften Europas. Siedlungsforschung 31:29-62

Rhemtulla JM, Mladenoff DJ (2007) Why history matters in landscape ecology. Landscape Ecol 22(suppl. 1):1-3

Schneeberger N, Bürgi M, Kienast F (2007) Rates of landscape change at the northern fringe of the Swiss Alps: historical and recent tendencies. Landsc Urban Plan 80:127-136

Schneider N, Eugster W (2007) Climatic impacts of historical wetland drainage in Switzerland. Clim Change 80:301-321

Seto KC, Fragkias M (2005) Quantifying spatiotemporal patterns of urban land-use change in four cities of China with time series landscape metrics. Landscape Ecol 20:871-888

Stähli H (1941) Das Limpachtal und seine Bodenverbesserung. Buchdruckerei Fritz Glauser, Fraubrunnen
Stähli H (1953) Die Melioration des Limpachtales: 1939-1951. Buchdruckerei Fritz Glauser, Fraubrunnen

Stouffer PC, Bierregaard RO Jr, Strong C, Lovejoy TE (2006) Long-term landscape change and bird abundance in Amazonian rainforest fragments. Conserv Biol 20:1212-1223

Straub A (2008) Die Gesamtmelioration des Limpachtals von 1939 bis 1951 - und ihr Folgen für die Landnutzung und Landwirtschaft. Thesis conducted at WSL, Birmensdorf \& University of Karlsruhe, Karlsruhe

Turner BL II, Lambin EF, Reenberg A (2007) The emergence of land change science for global environmental change and sustainability. Proc Natl Acad Sci 104:20666-20671 